Article

\title{
Dimacrolide Sesquiterpene Pyridine Alkaloids from the Stems of Tripterygium regelii
}

\author{
Dongsheng Fan, Guo-Yuan Zhu, Ting Li, Zhi-Hong Jiang * and Li-Ping Bai * \\ State Key Laboratory of Quality Research in Chinese Medicine, Macau Institute for Applied Research in \\ Medicine and Health, Macau University of Science and Technology, Taipa, Macau SAR, China; \\ fandongsheng1985@sina.com (D.F.); gyzhu@must.edu.mo (G.-Y.Z.); tli@must.edu.mo (T.L.) \\ * Correspondence: zhjiang@must.edu.mo (Z.-H.J.); lpbai@must.edu.mo (L.-P.B.); \\ Tel.: +853-8897-2777 (Z.-H.J.); +853-8897-2403 (L.-P.B.)
}

Academic Editor: Derek J. McPhee

Received: 20 July 2016; Accepted: 3 August 2016; Published: 29 August 2016

\begin{abstract}
Two new dimacrolide sesquiterpene pyridine alkaloids (DMSPAs), dimacroregelines A (1) and B (2), were isolated from the stems of Tripterygium regelii. The structures of both compounds were characterized by extensive 1D and 2D NMR spectroscopic analyses, as well as HRESIMS data. Compounds $\mathbf{1}$ and $\mathbf{2}$ are two rare DMSPAs possessing unique 2-(3'-carboxybutyl)-3-furanoic acid units forming the second macrocyclic ring, representing the first example of DMSPAs bearing an extra furan ring in their second macrocyclic ring system. Compound 2 showed inhibitory effects on the proliferation of human rheumatoid arthritis synovial fibroblast cell (MH7A) at a concentration of $20 \mu \mathrm{M}$.
\end{abstract}

Keywords: Tripterygium regelii; dimacrolide sesquiterpene pyridine alkaloids; anti-inflammation

\section{Introduction}

Celastraceae is a large family comprising about 97 genera and 1194 species, which are distributed mainly in the tropics and subtropics. Among them, 14 genera with 192 species are native to China [1]. Some plants from several genera including Tripterygium, Celastrus, Euonymus, and Maytenus, are used as folk medicines or traditional Chinese medicines [1,2]. Plants of this family are the richest source of diverse dihydro- $\beta$-agarofuran sesquiterpenoids, which have been considered as characteristic metabolites and chemotaxonomic markers of this family [3,4]. This class of sesquiterpenes has attracted researchers' interest because of a variety of promising bioactivities, such as anti-inflammatory, immunosuppressive, multidrug resistance reversal, cytotoxic, antitumor and anti-HIV activities, etc. [3,4].

Dimacrolide sesquiterpene pyridine alkaloids (DMSPAs) are a structurally unique class of dihydro- $\beta$-agarofuran sesquiterpenoids. They were characterized by a polyhydroxylated dihydroagarofuran core and two dicarboxylic acid derivatives linked via four ester bonds forming two macrocyclic systems. DMSPAs are a rare class of compounds naturally occurring in a limited number of plants, such as cathedulin E3 [5-8], cathedulin E4 [5-8], cathedulin-K19 [9], and cathedulin-K20 [9] from Catha edulis (Forsk), triptonine A [10,11] and triptonine B [10,11] from Tripterygium hypoglaucum, and tripterygiumine A [12] from Tripterygium wilfordii. Moreover, triptonine B has been reported to inhibit HIV replication with $\mathrm{EC}_{50}$ value $<0.10 \mu \mathrm{g} / \mathrm{mL}$ in $\mathrm{H} 9$ lymphocytes with a significant therapeutic index (TI) value (TI > 1000) [11].

Tripterygium regelii is distributed throughout northeast China, Korea and Japan [13], and has been used as a folk medicine in China to treat rheumatoid arthritis, jaundice, swelling, etc. [14]. A few earlier phytochemical studies on this plant showed the presence of diterpenoids [15], triterpenoids [16-20] and alkaloids $[21,22]$. Recently, twelve new dihydro- $\beta$-agarofuran sesquiterpenoids and three new 
triterpenoids have been isolated and identified from the stems of T. regelii in our laboratory $[23,24]$. During our ongoing search for secondary metabolites from T. regelii, this phytochemical investigation was extended, resulting in the isolation of two new DMSPAs 1 and 2 (Figure 1). Herein, we report the isolation and structural elucidation of both compounds, as well as their inhibitory effect on proliferation of human rheumatoid arthritis synovial fibroblast (MH7A) cells.

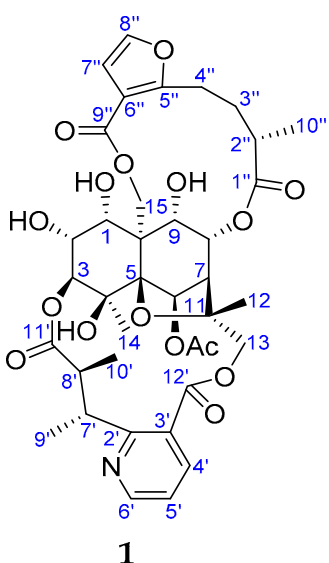

1

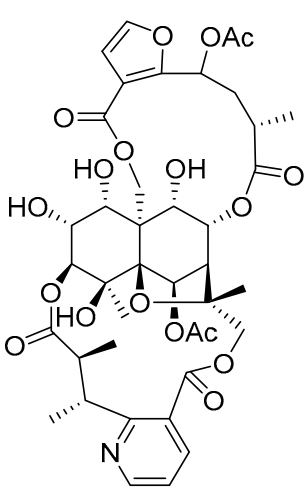

2

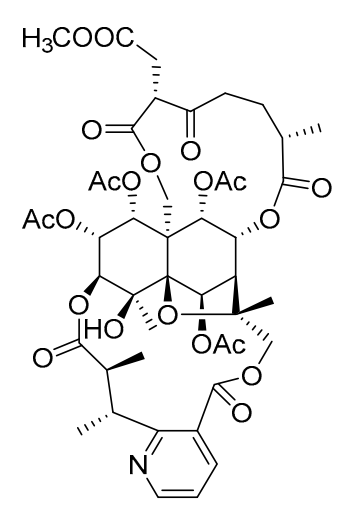

triptonine A

Figure 1. The chemical structures of compounds 1, 2 and triptonine A.

\section{Results and Discussion}

Compound 1 was obtained as a white amorphous powder. The molecular formula of $\mathrm{C}_{38} \mathrm{H}_{45} \mathrm{NO}_{16}$ was deduced from an $[\mathrm{M}+\mathrm{H}]^{+}$ion peak at $m / z 772.2820$ (calcd. for $\mathrm{C}_{38} \mathrm{H}_{46} \mathrm{NO}_{16}, 772.2811$ ) in the HRESIMS. Its UV spectrum showed absorption bands at $\lambda_{\max } 231$ and $253 \mathrm{~nm}$, indicating the presence of aromatic rings. In the ${ }^{1} \mathrm{H}-\mathrm{NMR}$ spectroscopic data of $\mathbf{1}$ (Table 1), resonances for six oxygenated methines $\left[\delta_{\mathrm{H}} 6.61(1 \mathrm{H}, \mathrm{s}, \mathrm{H}-6), 5.50(1 \mathrm{H}, \mathrm{dd}, J=6.0,3.6 \mathrm{~Hz}, \mathrm{H}-8), 4.75(1 \mathrm{H}, \mathrm{d}, J=3.0 \mathrm{~Hz}, \mathrm{H}-3)\right.$, $4.42(1 \mathrm{H}, \mathrm{d}, J=6.0 \mathrm{~Hz}, \mathrm{H}-9), 4.19(1 \mathrm{H}, \mathrm{d}, J=3.6 \mathrm{~Hz}, \mathrm{H}-1)$ and $3.84(1 \mathrm{H}, \mathrm{dd}, J=3.6,3.0 \mathrm{~Hz}, \mathrm{H}-2)]$, one methine $\left[\delta_{\mathrm{H}} 2.62(1 \mathrm{H}, \mathrm{d}, J=3.6 \mathrm{~Hz}, \mathrm{H}-7)\right]$, two oxygenated methylenes $\left[\delta_{\mathrm{H}} 5.96\right.$ and $3.84($ each $1 \mathrm{H}$, $\left.\mathrm{d}, J=11.4 \mathrm{~Hz}, \mathrm{H}_{2}-13\right) ; 5.62$ and 4.76 (each $\left.1 \mathrm{H}, \mathrm{d}, J=14.4 \mathrm{~Hz}, \mathrm{H}_{2}-15\right)$ ], one hydroxyl proton [4.64 (1H, s), $\mathrm{OH}-4]$, two tertiary methyl groups $\left[\delta_{\mathrm{H}} 1.61\right.$ and 1.58 (each $3 \mathrm{H}, \mathrm{s}, \mathrm{H}_{3}-12$ and $\mathrm{H}_{3}-14$ )] and an acetyl group $\left[\delta_{\mathrm{H}} 2.12(3 \mathrm{H}, \mathrm{s}, \mathrm{OAc}-6)\right]$ indicated the presence of a polyoxygenated dihydro- $\beta$-agarofuran sesquiterpene unit [23,25-28]. An evoninic acid moiety [25-29] was deduced by the signals for a 2,3-disubstituted pyridine $\left[\delta_{\mathrm{H}} 8.66\left(1 \mathrm{H}, \mathrm{dd}, J=4.8,1.8 \mathrm{~Hz}, \mathrm{H}-6^{\prime}\right), 8.16\left(1 \mathrm{H}, \mathrm{dd}, J=7.8,1.8 \mathrm{~Hz}, \mathrm{H}-4^{\prime}\right)\right.$ and $\left.7.39\left(1 \mathrm{H}, \mathrm{dd}, J=7.8,4.8 \mathrm{~Hz}, \mathrm{H}-5^{\prime}\right)\right]$, two methines [ $\delta_{\mathrm{H}} 4.62\left(1 \mathrm{H}, \mathrm{qd}, J=6.6,1.2 \mathrm{~Hz}, \mathrm{H}-7^{\prime}\right)$ and $2.44\left(1 \mathrm{H}\right.$, br q, $\left.\left.J=6.6 \mathrm{~Hz}, \mathrm{H}-8^{\prime}\right)\right]$, and two secondary methyl groups $\left[\delta_{\mathrm{H}} 1.36\right.$ and 1.13 (each $3 \mathrm{H}, \mathrm{d}$, $J=6.6 \mathrm{~Hz}, \mathrm{H}_{3}-9^{\prime}$ and $\left.\left.\mathrm{H}_{3}-10^{\prime}\right)\right]$. The remaining signals for a 2,3-disubstituted furan $\left[\delta_{\mathrm{H}} 7.42(1 \mathrm{H}, \mathrm{d}\right.$, $\left.\left.J=1.8 \mathrm{~Hz}, \mathrm{H}-8^{\prime \prime}\right), 6.73\left(1 \mathrm{H}, \mathrm{d}, J=1.8 \mathrm{~Hz}, \mathrm{H}-7^{\prime \prime}\right)\right]$, a methine $\left[\delta_{\mathrm{H}} 2.50\left(1 \mathrm{H}, \mathrm{m}, \mathrm{H}-2^{\prime \prime}\right)\right]$, two mehylenes $\left[\delta_{\mathrm{H}} 3.77\left(1 \mathrm{H}, \mathrm{m}, \mathrm{H}-4^{\prime \prime} \mathrm{a}\right)\right.$ and $2.96\left(1 \mathrm{H}, \mathrm{ddd}, J=14.4,7.2,4.2 \mathrm{~Hz}, \mathrm{H}-4{ }^{\prime \prime} \mathrm{b}\right) ; 2.06$ and 1.91 (each 1H, m, $\left.\left.\mathrm{H}_{2}-3^{\prime \prime}\right)\right]$, and one secondary methyl group $\left[\delta_{\mathrm{H}} 1.14\left(3 \mathrm{H}, \mathrm{d}, J=7.2 \mathrm{~Hz}, \mathrm{H}-10^{\prime \prime}\right)\right.$ ] were attributed to a 2-(3'-carboxybutyl)-3-furanoic acid unit in the ${ }^{1} \mathrm{H}-\mathrm{NMR}$ spectrum. The ${ }^{13} \mathrm{C}$-NMR spectroscopic data (Table 1) along with DEPT and HSQC spectra showed the presence of the units mentioned above in 1. These characteristic NMR data suggested 1 to be a dimacrolide sesquiterpene pyridine alkaloid [5-12]. The ${ }^{1} \mathrm{H}$ - and ${ }^{13} \mathrm{C}-\mathrm{NMR}$ data (Table 1) of $\mathbf{1}$ were similar to those of triptonine A [10], previously isolated from T. hypoglaucum, except for the following two differences: one difference was the different chemical shifts of C-5", C-6", C-7" and C-8" in 1 from those in triptonine A due to the presence of a furan group in the second macrocyclic ring system in 1. The 2-(3'-carboxybutyl)-3-furanoic acid unit was disclosed from ${ }^{1} \mathrm{H}-{ }^{1} \mathrm{H}$ COSY correlations of $\mathrm{H}_{3}-10^{\prime \prime} / \mathrm{H}_{1}-2^{\prime \prime} / \mathrm{H}_{2}-3^{\prime \prime} / \mathrm{H}_{2}-4^{\prime \prime}$ and $\mathrm{H}-7^{\prime \prime} / \mathrm{H}-8$ ", and the key HMBC correlations from H-3" and H-10 " to C-1", from H-4" to C-6", from H-7" to C-5", C-6", C-8" and C-9", and from H-8" to C-5", C-6" and C-7" (Figure 2A). The linkages of 2-(3'-carboxybutyl)-3-furanoic 
acid unit and dihydro- $\beta$-agarofuran sesquiterpene core were via $\mathrm{C}-8-\mathrm{O}-\mathrm{C}-\mathrm{1}^{\prime \prime}$ and $\mathrm{C}-15-\mathrm{O}-\mathrm{C}-9^{\prime \prime}$, as deduced from the key HMBC correlations from $\mathrm{H}-8\left(\delta_{\mathrm{H}} 5.50\right)$ and $\mathrm{H}_{2}-15\left(\delta_{\mathrm{H}} 5.62\right.$ and 4.76) to the carbonyl carbons $\left(\delta_{C} 177.1, C-1 "\right)$ and $\left(\delta_{C} 166.2, C-9^{\prime \prime}\right)$, respectively. The other key difference was the absence of three acetyl groups and the upfield shifts of $\mathrm{H}-1\left(\delta_{\mathrm{H}} 4.19\right), \mathrm{H}-2\left(\delta_{\mathrm{H}} 3.84\right)$ and $\mathrm{H}-9\left(\delta_{\mathrm{H}} 4.42\right)$ relative to those $\left(\delta_{\mathrm{H}} 5.46,5.15\right.$, and 5.25 , respectively) in triptonine $A$, which suggested deacetylation of the C-1, C-2 and C-9 in $\mathbf{1}$. Therefore, the proposed planar structure of $\mathbf{1}$ was established and further confirmed by the ${ }^{1} \mathrm{H}^{-}{ }^{1} \mathrm{H}$ COSY and HMBC analyses (Figure 2A).

Table 1. ${ }^{1} \mathrm{H}-(600 \mathrm{MHz})$ and ${ }^{13} \mathrm{C}-(150 \mathrm{MHz})$ NMR spectroscopic data for $\mathbf{1}$ and 2 in $\mathrm{CD}_{3} \mathrm{OD}$.

\begin{tabular}{|c|c|c|c|c|}
\hline \multirow{2}{*}{ Position } & \multicolumn{2}{|l|}{1} & \multicolumn{2}{|l|}{2} \\
\hline & $\delta_{H}(J$ in $\mathbf{H z})$ & $\delta_{C}$, Type & $\delta_{H}(J$ in $\mathrm{Hz})$ & $\delta_{C}$, Type \\
\hline 1 & $4.19, \mathrm{~d}(3.6)$ & $75.4, \mathrm{CH}$ & $4.24, \mathrm{~d}(3.6)$ & $74.9, \mathrm{CH}$ \\
\hline 2 & $3.84, \mathrm{dd}(3.6,3.0)$ & $73.0, \mathrm{CH}$ & 3.83, dd $(3.6,2.4)$ & $73.0, \mathrm{CH}$ \\
\hline 3 & $4.75, \mathrm{~d},(3.0)^{\mathrm{a}}$ & $80.4, \mathrm{CH}$ & $4.79, \mathrm{~d}(2.4)$ & $80.2, \mathrm{CH}$ \\
\hline 4 & & $72.2, \mathrm{C}$ & & $72.3, \mathrm{C}$ \\
\hline 5 & & $95.3, \mathrm{C}$ & & $94.9, \mathrm{C}$ \\
\hline 6 & $6.61, \mathrm{~s}$ & $76.6, \mathrm{CH}$ & $6.20, \mathrm{~s}$ & $78.5, \mathrm{CH}$ \\
\hline 7 & $2.62, \mathrm{~d}(3.6)$ & $51.1, \mathrm{CH}$ & $2.94, \mathrm{~d}(4.2)$ & $50.0, \mathrm{CH}$ \\
\hline 8 & $5.50, \mathrm{dd}(6.0,3.6)$ & $72.9, \mathrm{CH}$ & 5.44, dd $(6.0,4.2)$ & $73.4, \mathrm{CH}$ \\
\hline 9 & $4.42, \mathrm{~d}(6.0)$ & $73.6, \mathrm{CH}$ & $4.43, \mathrm{~d}(6.0)$ & $73.7, \mathrm{CH}$ \\
\hline 10 & & $54.8, \mathrm{C}$ & & $55.2, \mathrm{C}$ \\
\hline 11 & & $85.1, \mathrm{C}$ & & $84.7, \mathrm{C}$ \\
\hline 12 & $1.61, \mathrm{~s}$ & $18.4, \mathrm{CH}_{3}$ & $1.59, \mathrm{~s}$ & $18.2, \mathrm{CH}_{3}$ \\
\hline $13 \mathrm{a}$ & $5.96, \mathrm{~d}(11.4)$ & $71.6, \mathrm{CH}_{2}$ & $5.78, \mathrm{~d}(11.4)$ & $71.4, \mathrm{CH}_{2}$ \\
\hline $13 \mathrm{~b}$ & $3.84, \mathrm{~d}(11.4)^{\mathrm{a}}$ & & $3.81, \mathrm{~d}(11.4)$ & \\
\hline 14 & $1.58, \mathrm{~s}$ & $24.1, \mathrm{CH}_{3}$ & $1.77, \mathrm{~d}(0.6)$ & 24.6, $\mathrm{CH}_{3}$ \\
\hline $15 \mathrm{a}$ & $5.62, \mathrm{~d}(14.4)$ & $63.2, \mathrm{CH}_{2}$ & $5.21, \mathrm{~d}(14.4)$ & $64.1, \mathrm{CH}_{2}$ \\
\hline $15 \mathrm{~b}$ & $4.76, \mathrm{~d}(14.4)^{\mathrm{a}}$ & & $5.01, \mathrm{~d}(14.4)$ & \\
\hline $2^{\prime}$ & & $165.7, \mathrm{C}$ & & 165.3, C \\
\hline $3^{\prime}$ & & $127.2, \mathrm{C}$ & & $127.4, \mathrm{C}$ \\
\hline $4^{\prime}$ & $8.16, \mathrm{dd}(7.8,1.8)$ & $139.2, \mathrm{CH}$ & $8.13, \mathrm{dd}(7.8,1.8)$ & $139.0, \mathrm{CH}$ \\
\hline $5^{\prime}$ & $7.39, \mathrm{dd}(7.8,4.8)$ & $122.8, \mathrm{CH}$ & 7.39, dd $(7.8,4.8)$ & $122.8, \mathrm{CH}$ \\
\hline $6^{\prime}$ & $8.66, \mathrm{dd}(4.8,1.8)$ & $152.4, \mathrm{CH}$ & $8.66, \mathrm{dd}(4.8,1.8)$ & $152.4, \mathrm{CH}$ \\
\hline $7^{\prime}$ & $4.62, \mathrm{qd}(6.6,1.2)^{\mathrm{a}}$ & $37.6, \mathrm{CH}$ & $4.57, \mathrm{qd}(6.6,1.2)^{\mathrm{a}}$ & $37.7, \mathrm{CH}$ \\
\hline $8^{\prime}$ & 2.44, br q $(6.6)$ & $46.3, \mathrm{CH}$ & $2.46, \mathrm{qd}(6.6,1.2)$ & $46.2, \mathrm{CH}$ \\
\hline $9^{\prime}$ & $1.36, \mathrm{~d}(6.6)$ & $12.0, \mathrm{CH}_{3}$ & $1.36, \mathrm{~d}(6.6)$ & $12.2, \mathrm{CH}_{3}$ \\
\hline $10^{\prime}$ & $1.13, \mathrm{~d}(6.6)$ & $9.8, \mathrm{CH}_{3}$ & $1.16, \mathrm{~d}(6.6)$ & $9.9, \mathrm{CH}_{3}$ \\
\hline $11^{\prime}$ & & $175.9, \mathrm{C}$ & & $175.9, \mathrm{C}$ \\
\hline $12^{\prime}$ & & $170.1, \mathrm{C}$ & & $170.0, \mathrm{C}$ \\
\hline $1^{\prime \prime}$ & & 177.1, C & & $176.5, \mathrm{C}$ \\
\hline $2 "$ & $2.50, \mathrm{~m}$ & $38.0, \mathrm{CH}$ & $2.16, \mathrm{~m}$ & $35.5, \mathrm{CH}$ \\
\hline $3 " \mathrm{a}$ & $2.06, \mathrm{~m}$ & $33.2, \mathrm{CH}_{2}$ & $2.36, \operatorname{td}(12.6,4.8)$ & $37.9, \mathrm{CH}_{2}$ \\
\hline $3^{\prime \prime} \mathrm{b}$ & $1.91, \mathrm{~m}$ & & $2.25, \operatorname{td}(12.6,1.8)$ & \\
\hline $4^{\prime \prime} \mathrm{a}$ & $3.77, \mathrm{~m}$ & $26.8, \mathrm{CH}_{2}$ & $6.89, \mathrm{dd}(12.6,4.8)$ & $68.0, \mathrm{CH}$ \\
\hline $4^{\prime \prime} \mathrm{b}$ & 2.96, ddd $(14.4,7.2,4.2)$ & & & \\
\hline $5^{\prime \prime}$ & & 161.3, C & & 154.3, C \\
\hline $6^{\prime \prime}$ & & $116.0, \mathrm{C}$ & & $119.9, \mathrm{C}$ \\
\hline $7^{\prime \prime}$ & $6.73, \mathrm{~d}(1.8)$ & $113.4, \mathrm{CH}$ & $6.80, \mathrm{~d}(1.8)$ & $113.5, \mathrm{CH}$ \\
\hline $8^{\prime \prime}$ & $7.42, \mathrm{~d}(1.8)$ & $142.3, \mathrm{CH}$ & $7.58, \mathrm{~d}(1.8)$ & 144.1, CH \\
\hline $9^{\prime \prime}$ & & $166.2, \mathrm{C}$ & & $165.6, \mathrm{C}$ \\
\hline $10^{\prime \prime}$ & $1.14, \mathrm{~d}(7.2)$ & $17.4, \mathrm{CH}_{3}$ & $1.10, \mathrm{~d}(6.6)$ & $17.7, \mathrm{CH}_{3}$ \\
\hline $\mathrm{OH}-4$ & $4.64, \mathrm{~s}^{\mathrm{a}}$ & & $4.57, \mathrm{~s}^{\mathrm{a}}$ & \\
\hline OAc-6 & $2.12, \mathrm{~s}$ & $\begin{array}{c}21.5, \mathrm{CH}_{3} \\
171.3, \mathrm{C}\end{array}$ & $2.09, \mathrm{~s}$ & $\begin{array}{c}21.7, \mathrm{CH}_{3} \\
171.9, \mathrm{C}\end{array}$ \\
\hline OAc-4" & & & $1.96, \mathrm{~s}$ & $\begin{array}{c}20.9, \mathrm{CH}_{3} \\
171.6, \mathrm{C}\end{array}$ \\
\hline
\end{tabular}

${ }^{\text {a }}$ The overlapped signals were assigned from ${ }^{1} \mathrm{H}^{-1} \mathrm{H}$ COSY, HSQC, and HMBC spectra.

The relative configuration of the dihydro- $\beta$-agarofuran sesquiterpene core in $\mathbf{1}$ was assigned by the NOESY correlations (Figure 2B) and coupling constant. The NOE correlations of $\mathrm{H}-1 / \mathrm{H}-9$, 
H-9/ $\mathrm{H}_{3}-12$ and $\mathrm{H}_{3}-12 / \mathrm{H}-8$ suggested that these protons were on the same face. NOE effects of $\mathrm{H}_{3}-14 / \mathrm{H}-3, \mathrm{H}_{3}-14 / \mathrm{H}-6$ and $\mathrm{H}_{3}-14 / \mathrm{H}_{2}-15$ were observed, showing that these protons were on the other face. The small coupling constant of $J_{1,2}=3.6 \mathrm{~Hz}$ between $\mathrm{H}-1$ and $\mathrm{H}-2$ indicated that the H-2 was equatorial. These data revealed that the relative configuration of the dihydro- $\beta$-agarofuran sesquiterpene core in 1 was identical to that of triptonine A [10] and the related compounds [12,27,28]. The relative configurations of the groups at two macrocyclic rings were determined by comparison of the NMR spectroscopic data with those of triptonine A [10], which was established by X-ray crystallography. As the ${ }^{1} \mathrm{H}$ and ${ }^{13} \mathrm{C}$ data of 1 were closely similar to those of triptonine $\mathrm{A}$ except for positions C-5", C-6", C-7" and C-8', it could indicate the same relative configurations at C-7', C- ${ }^{\prime}$ and $\mathrm{C}-2^{\prime \prime}$ in the macrocyclic rings. Therefore, compound $\mathbf{1}$ was identified as shown in Figure 1, and given a trivial name of dimacroregeline A.
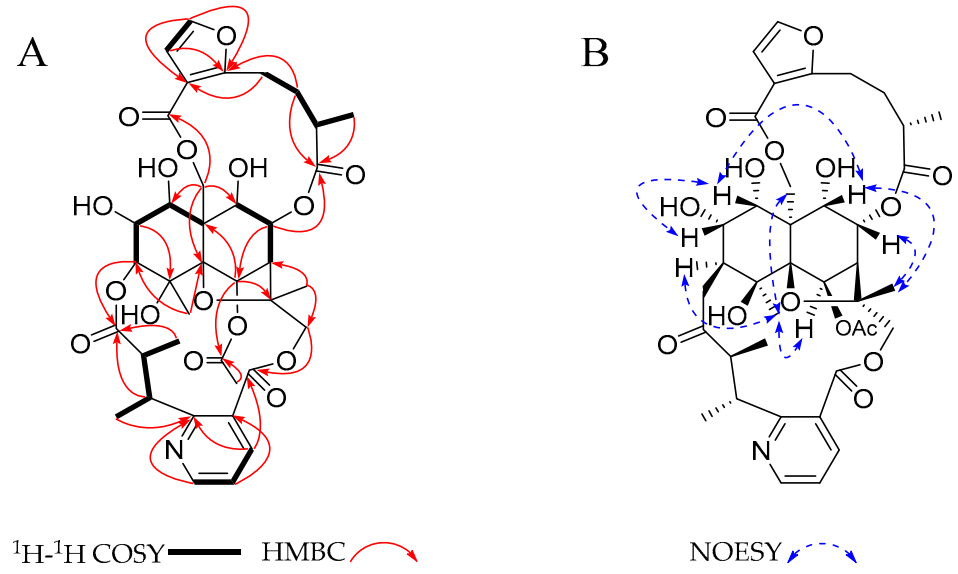

Figure 2. The ${ }^{1} \mathrm{H}_{-}{ }^{1} \mathrm{H}$ COSY, key HMBC and selected NOESY correlations of $\mathbf{1}$.

Compound 2 was isolated as a white amorphous powder. The molecular formula was determined as $\mathrm{C}_{40} \mathrm{C}_{47} \mathrm{NO}_{18}$ on the basis of a protonated molecule at $m / z 830.2876[\mathrm{M}+\mathrm{H}]^{+}$(calcd for $\mathrm{C}_{40} \mathrm{C}_{48} \mathrm{NO}_{18}$, 830.2866), which was 58.0056 mass units more than that of $\mathbf{1}$ in the HRESIMS. The ${ }^{1} \mathrm{H}$ and ${ }^{13} \mathrm{C}-\mathrm{NMR}$ spectroscopic data of 2 (Table 1) were closely similar to those of $\mathbf{1}$ except for the absence of C-4" methylene group and the presence of an additional oxygenated methine $\left(\delta_{\mathrm{H}} 6.89, \delta_{\mathrm{C}} 68.0, \mathrm{CH}-4^{\prime \prime}\right)$ and an extra acetyl group $\left(\delta_{\mathrm{H}} 1.96, \delta_{\mathrm{C}} 171.6\right.$ and 20.9$)$. The methylene group $\left(\delta_{\mathrm{H}} 3.77\right.$ and 2.96) at C-4" in 1 was displaced by the oxygenated methine $\left(\delta_{\mathrm{H}} 6.89, \mathrm{H}-4^{\prime \prime}\right)$ in 2 , supported by the observation of HMBC correlation from the oxygenated methine $\left(\delta_{\mathrm{H}} 6.89\right)$ to the carbon signal $\left(\delta_{\mathrm{C}} 37.9\right)$ at $\mathrm{C}-3$ " in 2 . The acetyl group $\left(\delta_{\mathrm{H}} 1.96, \delta_{\mathrm{C}} 171.6\right.$ and 20.9$)$ was allocated to $C-4^{\prime \prime}$ in 2 , as evidenced from the HMBC correlation from H-4" signal $\left(\delta_{\mathrm{H}} 6.89\right)$ to the carbonyl carbon $\left(\delta_{\mathrm{C}} 171.6\right)$ of the acetyl group. Thus, compound 2 was elucidated as shown in Figure 1, and named dimacroregeline B.

So far, only seven dimacrolide sesquiterpene pyridine alkaloids [5-12] have been isolated from plants. Compounds 1 and 2 represent the first example of dimacrolide sesquiterpene pyridine alkaloids bearing an extra furan ring in their second macrocyclic ring system. The HRMS, UV, NMR and CD spectra of compounds 1 and $\mathbf{2}$ were shown in the supplementary materials (Figures S1-S18).

Over the past several decades, many monomacrolide sesquiterpene pyridine alkaloids have been identified from the plants in the family Celastraceae, especially Tripterygium [3,4], the proposed biosynthetic pathways for dihydro- $\beta$-agarofuran sesquiterpene unit and pyridine dicarboxylic acid moiety have been disclosed [9,30,31]. The biosynthetic pathway of 2-(3'-carboxybutyl)-3-furanoic acid unit was proposed as shown in Scheme 1, since this unit was reported in nature for the first time. The 3-furanoic acid residue is regarded as its biosynthetic precursor, which could generate this unit via prenylation under catalysis in plants [32]. 


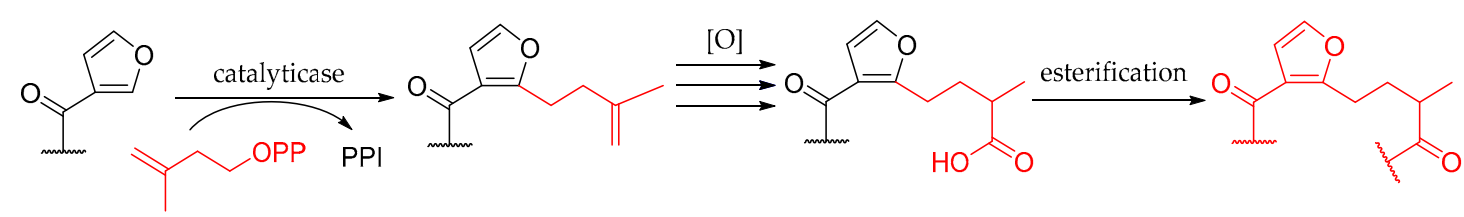

Scheme 1. Plausible biosynthetic pathway for 2-(3'-carboxybutyl)-3-furanoic acid unit.

It is well known that activated synovial fibroblasts play a crucial role in the pathogenesis of rheumatoid arthritis (RA), which could result in the cartilage destruction and synovial inflammation [33-35]. The inhibition of the synovial fibroblast proliferation is considered as a promising treatment for RA. Thus, compounds $\mathbf{1}$ and $\mathbf{2}$ were evaluated for anti-proliferative activity against human rheumatoid arthritis synovial fibroblast cell line (MH7A). As the result (Table 2), compound 2 inhibited proliferation of MH7A cells $(p<0.05)$ by $13.3 \%$ at the concentration of $20 \mu \mathrm{M}$ compared with the vehicle control.

Table 2. Effect of compounds 1 and 2 on the viability of MH7A cell.

\begin{tabular}{ccc}
\hline Compounds $^{\#}$ & Cell Viability $(\mathbf{\%})(\boldsymbol{n}=\mathbf{3})$ & Inhibition Rate $(\mathbf{\%})$ \\
\hline Vehicle control & $100 \pm 5.9$ & 0 \\
$\mathbf{1}$ & $94.6 \pm 5.4$ & $5.4 \pm 5.4$ \\
$\mathbf{2}$ & $86.7 \pm 5.2 *$ & $13.3 \pm 5.2 *$ \\
\hline
\end{tabular}

* There was a significant difference $(p<0.05)$ between the group treated with compound 2 and the control group treated with the vehicle; ${ }^{\#}$ Compounds 1 and 2 were tested at the concentration of $20 \mu \mathrm{M}$.

\section{Materials and Methods}

\subsection{General Procedures}

Optical rotations and ultraviolet (UV) spectra were recorded on a Rudolph Research Analytical Autopol I automatic polarimeter (Rudolph Research Analytical, Hackettstown, NJ, USA) and a DU ${ }^{\circledR}$ 800 spectrophotometer (Beckman Coulter, Fullerton, CA, USA), respectively. Circular dichroism spectra were measured on a Jasco J1500 CD spectrometer (Jasco Corperation, Tokyo, Japan). Nuclear magnetic resonance (NMR) spectra were acquired with an Ascent $600 \mathrm{NMR}$ spectrometer at $600 \mathrm{MHz}$ for ${ }^{1} \mathrm{H}-\mathrm{NMR}$ and $150 \mathrm{MHz}$ for ${ }^{13} \mathrm{C}-\mathrm{NMR}$ (Bruker, Zurich, Switzerland). The samples dissolved in $\mathrm{CD}_{3} \mathrm{OD}$ with residual solvent as an internal reference. HRMS spectra were performed on a 6230 electrospray ionization (ESI) time-of-flight (TOF) mass spectrometer (Agilent, Santa Clara, CA, USA) in the positive ion mode. Medium pressure liquid chromatography (MPLC) was carried out on a Sepacore Flash Chromatography System (Buchi, Flawil, Switzerland) using a flash column $(460 \times 36 \mathrm{~mm}$, i.d., Buchi) packed with Bondapak Waters ODS (40-63 $\mu \mathrm{m}$, Waters, Milford, MA, USA). Preparative HPLC was conducted on a Waters liquid chromatography system coupled with 1525 Binary HPLC Pump and $2489 \mathrm{UV} /$ Visible detector using a Waters Xbridge Prep $C_{8}$ column $(10 \times 250 \mathrm{~mm}, 5 \mu \mathrm{m})$. Semi-preparative HPLC was performed on an Agilent 1100 liquid chromatography system equipped with a quaternary pump and a diode array detector (DAD) using a Waters Xbridge Prep $\mathrm{C}_{18}$ column $(10 \times 250 \mathrm{~mm}, 5 \mu \mathrm{m})$. Silica gel $(40-60 \mu \mathrm{m}$, Grace, Columbia, MD, USA) was used for column chromatography. Thin layer chromatography (TLC) was performed on precoated silica gel $60 \mathrm{~F}_{254}$ plates and TLC silica gel 60 RP-18 F $_{254 S}$ plates ( $200 \mu \mathrm{m}$ thick, Merck KGaA, Darmstadt, Germany).

\subsection{Plant Material}

The stems of T. regelii were collected from Changbai Mountain in Jilin Province, China, in October 2012, and authenticated by Dr. Liang Xu, School of Pharmacy, Liaoning University of Traditional Chinese Medicine, Dalian, China. A voucher specimen (No. MUST-TR201210) has been 
deposited at State Key Laboratory of Quality Research in Chinese Medicine, Macau University of Science and Technology, Macau, China.

\subsection{Extraction and Isolation}

The air-dried and crushed stems of T. regelii $(8.0 \mathrm{~kg})$ were extracted three times with $\mathrm{MeOH}$ $(64 \mathrm{~L})$ under ultrasound at room temperature for $1 \mathrm{~h}$. A dark brown residue was obtained after removing the solvent under reduced pressure, which was suspended in $\mathrm{H}_{2} \mathrm{O}$, and then partitioned with $n$-hexane, EtOAc and $n$-butanol. The EtOAc-soluble extract $(150.0 \mathrm{~g})$ was chromatographed over a silica gel column and eluted with petroleum ether-acetone $(100: 0-35: 65, v / v)$ to give thirteen fractions (Fr. 1-Fr.13). The Fr.12 (9.0 g) was separated by MPLC with a gradient of $\mathrm{MeOH}-\mathrm{H}_{2} \mathrm{O}$ (5:95-100:0, $50 \mathrm{~mL} / \mathrm{min}$ ) to afford six fractions (Fr.12-1-Fr.12-6). The Fr.12-5 showed the alkaloid-positive test after spraying with Dragendorff's reagent. Then, Fr.12-5 (350 mg) was separated by preparative HPLC using MeCN- $\mathrm{H}_{2} \mathrm{O}(42: 58, v / v)$ as mobile phase to give eleven fractions (Fr.12-5-1-Fr.12-5-11). Fr.12-5-2 (50 mg) was isolated by semi-preparative HPLC with a $\mathrm{MeCN}-\mathrm{H}_{2} \mathrm{O}(39: 61, v / v)$ solvent system to afford compound $2(1.22 \mathrm{mg}$ ) and subfraction 12-5-2-3 (5 mg). Then, the subfraction 12-5-2-3 was further purified by semi-preparative HPLC using $\mathrm{MeOH}-\mathrm{H}_{2} \mathrm{O}(40: 60, v / v)$ as mobile phase to yield compound $\mathbf{1}(1.01 \mathrm{mg})$.

Dimacroregeline A (1) White amorphous powder; $[\alpha]_{\mathrm{D}}^{25}-19.8(c$ 0.25, $\mathrm{MeOH})$; UV (MeOH) $\lambda_{\max }$ $(\log \varepsilon) 231$ (3.95), 253 (3.84) nm; CD $\left(c 6.5 \times 10^{-4} \mathrm{~mol} / \mathrm{L}, \mathrm{MeOH}\right) \lambda_{\max }(\Delta \varepsilon) 200$ (+14.60), 216 (sh) (+3.96), $241(-3.96) \mathrm{nm} ;{ }^{1} \mathrm{H}-\mathrm{NMR}\left(\mathrm{CD}_{3} \mathrm{OD}\right)$ and ${ }^{13} \mathrm{C}-\mathrm{NMR}\left(\mathrm{CD}_{3} \mathrm{OD}\right)$ data, see Table 1 ; HRESIMS $\mathrm{m} / \mathrm{z}$ $772.2820[\mathrm{M}+\mathrm{H}]^{+}$(calcd for $\mathrm{C}_{38} \mathrm{H}_{46} \mathrm{NO}_{16}, 772.2811$ ), HRESIMS $m / z 794.2634[\mathrm{M}+\mathrm{Na}]^{+}$(calcd. for $\mathrm{C}_{38} \mathrm{H}_{45} \mathrm{NO}_{16} \mathrm{Na}$, 794.2631).

Dimacroregeline B (2) White amorphous powder; $[\alpha]_{\mathrm{D}}^{25}+4.0(c 0.50, \mathrm{MeOH}) ; \mathrm{UV}(\mathrm{MeOH}) \lambda_{\max }(\log \varepsilon)$ 228 (3.98), $260(3.65) \mathrm{nm} ; \mathrm{CD}\left(c 6.0 \times 10^{-4} \mathrm{~mol} / \mathrm{L}, \mathrm{MeOH}\right) \lambda_{\max }(\Delta \varepsilon) 233(+22.64), 245$ (+17.36), $276(-2.90) \mathrm{nm} ;{ }^{1} \mathrm{H}-\mathrm{NMR}\left(\mathrm{CD}_{3} \mathrm{OD}\right)$ and ${ }^{13} \mathrm{C}-\mathrm{NMR}\left(\mathrm{CD}_{3} \mathrm{OD}\right)$ data, see Table 1; HRESIMS $\mathrm{m} / \mathrm{z}$ $830.2876[\mathrm{M}+\mathrm{H}]^{+}$(calcd for $\left.\mathrm{C}_{40} \mathrm{H}_{48} \mathrm{NO}_{18}, 830.2866\right)$, HRESIMS $m / z 852.2695[\mathrm{M}+\mathrm{Na}]^{+}$(calcd. for $\mathrm{C}_{40} \mathrm{H}_{47} \mathrm{NO}_{18} \mathrm{Na}$, 852.2685).

\subsection{Inhibition of Proliferation on MH7A Human Synovial Cells}

MH7A cells were obtained from American Type Culture Collection (ATCC, Manassas, VA, USA). Cells were cultured in a Dulbecco's modified Eagle medium (DMEM) supplemented with $10 \%$ fetal bovine serum (FBS, Invitrogen, Carlsbad, CA, USA) and 1\% penicillin-streptomycin (Sigma, St. Louis, $\mathrm{MO}, \mathrm{USA})$ at $37^{\circ} \mathrm{C}$ in humidified atmosphere containing $5 \% \mathrm{CO}_{2}$. MTT [3-(4,5-dimethylthiazol-2-yl)2,5-diphenyl tetrazolium bromide] was employed to determine the cell viability as described previously [36,37]. Briefly, $5 \times 10^{3}$ cells/well MH7A cells (total $100 \mu \mathrm{L}$ ) were cultured in triplicate in a 96-well plate with or without $20 \mu \mathrm{M}$ compounds for $48 \mathrm{~h}$ incubation at $37^{\circ} \mathrm{C}$ in humidified atmosphere containing $5 \% \mathrm{CO}_{2}$. MTT $(5 \mathrm{mg} / \mathrm{mL}, 10 \mu \mathrm{L})$ was added into each well and incubated for $4 \mathrm{~h}$ before terminating the culture. The supernatant was gently removed, and the formazan in each well was dissolved in the lysing solvent (10\% sodium dodecyl sulfate (SDS), 50\% $\mathrm{N}, \mathrm{N}$-dimethylformamide, $\mathrm{pH}$ 7.2). Absorbance at $570 \mathrm{~nm}$ was determined using a microplate reader (Infinite $200 \mathrm{PRO}$, Tecan, Männedorf, Switzerland) from each well on the next day. The percentage of cell viability was calculated using the following formula: Cell viability $(\%)=$ (Absorbance of treated with compounds $/$ Absorbance of treated with control vehicle) $\times 100$. Data reported represent three independent experiments. Data are expressed as means \pm SEM. One-way ANOVA was used to determine the significance of difference. A value of $p<0.05$ was considered statistically significant.

Supplementary Materials: Supplementary materials can be accessed at: http://www.mdpi.com/1420-3049/21/ 9/1146/s1. 
Acknowledgments: This research was supported financially by Macao Science and Technology Development Fund, MSAR (Grant No. 056/2013/A2, and 063/2011/A3).

Author Contributions: Li-Ping Bai and Zhi-Hong Jiang conceived and designed the experiments; Dongsheng Fan and Guo-Yuan Zhu performed the isolation and structural elucidation of compounds 1 and 2; Ting Li performed the bioassay of both compounds; Dongsheng Fan and Li-Ping Bai wrote the paper; Li-Ping Bai and Zhi-Hong Jiang revised the manuscript.

Conflicts of Interest: The authors declare no conflict of interest.

\section{References}

1. Editorial Committee of Flora of China. Flora of China (English Revised Version); Science Press and Missouri Botanical Garden Press: Beijing, China; St. Louis, MO, USA, 2013; Volume 11, p. 439.

2. González, A.G.; Bazzocchi, I.L.; Moujir, L.; Jiménez, I.A. Ethnobotanical uses of celastraceae. Bioactive metabolites. Stud. Nat. Prod. Chem. 2000, 23, 649-738.

3. Spivey, A.C.; Weston, M.; Woodhead, S. Celastraceae sesquiterpenoids: Biological activity and synthesis. Chem. Soc. Rev. 2002, 31, 43-59. [CrossRef] [PubMed]

4. Gao, J.M.; Wu, W.J.; Zhang, J.W.; Konishi, Y.S. The dihydro- $\beta$-agarofuran sesquiterpenoids. Nat. Prod. Rep. 2007, 24, 1153-1189. [CrossRef] [PubMed]

5. Baxter, R.L.; Crombie, L.; Simmonds, D.J.; Whiting, D.A. Extractives of Catha edulis (Khat): Occurrence of celastraceaeous alkaloids having mono-and bis-macrolide bridges. J. Chem. Soc. Chem. Commun. 1976, 463-465. [CrossRef]

6. Baxter, R.L.; Crombie, L.; Simmonds, D.J.; Whiting, D.A.; Braenden, O.J.; Szendrei, K. Alkaloids of catha edulis (khat). Part 1. Isolation and characterisation of eleven new alkaloids with sesquiterpene cores (cathedulins); identification of the quinone-methide root pigments. J. Chem. Soc. Perkin Trans. 1 1979, 2965-2971. [CrossRef]

7. Crombie, L.; Crombie, W.M.L.; Whiting, D.A.; Branenden, O.J.; Szendrei, K. Structures of cathedulin alkaloids from Catha edulis (khat) of Kenyan and Ethiopian origin. J. Chem. Soc. Chem. Commun. 1978, 107-108. [CrossRef]

8. Baxter, R.L.; Crombie, W.M.L.; Crombie, L.; Simmonds, D.J.; Whiting, D.A.; Szendrei, K. Alkaloids of Catha edulis. Part 4. Structures of cathedulins E3, E4, E5, E6, and K12. Novel sesquiterpene alkaloids with mono-and bismacrolide bridges. J. Chem. Soc. Perkin Trans. 1 1979, 2982-2989. [CrossRef]

9. Crombie, L.; Toplis, D.; Whiting, D.A.; Rozsá, Z.; Hohmann, J.; Szendrei, K. New macrolide sesquiterpene alkaloids of Catha edulis: Examples containing a novel dilactone bridge. J. Chem. Soc. Perkin Trans. 1 1986, 531-534. [CrossRef]

10. Duan, H.; Takaishi, Y.; Bando, M.; Kido, M.; Imakura, Y.; Lee, K. Novel sesquiterpene esters with alkaloid and monoterpene and related compounds from Tripterygium hypoglaucum: A new class of potent anti-HIV agents. Tetrahedron Lett. 1999, 40, 2969-2972. [CrossRef]

11. Duan, H.; Takaishi, Y.; Imakura, Y.; Jia, Y.; Li, D.; Cosentino, L.M.; Lee, K.H. Sesquiterpene Alkaloids from Tripterygium hypoglaucum and Tripterygium wilfordii: A new class of potent anti-HIV agents. J. Nat. Prod. 2000, 63, 357-361. [CrossRef] [PubMed]

12. Luo, Y.; Pu, X.; Luo, G.; Zhou, M.; Ye, Q.; Liu, Y.; Gu, J.; Qi, H.; Li, G.; Zhang, G. Nitrogen-containing dihydro- $\beta$-agarofuran derivatives from Tripterygium wilfordii. J. Nat. Prod. 2014, 77, 1650-1657. [CrossRef] [PubMed]

13. Flora of China Editorial Committee of Chinese Academy of Sciences. Flora of China; Beijing Science and Technology Press: Beijing, China, 1999; Volume 45, p. 181.

14. Editorial Board of Zhonghua Bencao. Zhonghua Bencao; Shanghai Science and Technology Press: Shanghai, China, 1999; Volume 5, pp. 205-206.

15. Shen, J.H.; Zhou, B.N. Studies on diterpene-quinones of Tripterygium regelii Sprague. Chin. Chem. Lett. 1992, 3, 113-116.

16. Hori, H.; Pang, G.M.; Harimaya, K.; Iitaka, Y.; Inayama, S. Isolation and structure of regelin and regelinol, new antitumor ursene-type triterpenoids from Tripterygium regelii. Chem. Pharm. Bull. 1987, 35, 2125-2128. [CrossRef] [PubMed] 
17. Harada, R.; Kakisawa, H.; Kobayashi, S.; Musya, M.; Nakanishi, K.; Takahashi, Y. Structure of pristimerin, a quinonoid triterpene. Tetrahedron Lett. 1962, 3, 603-607. [CrossRef]

18. Pang, G.M.; Zhao, C.J.; Hori, H.; Inayama, S. Studies on new triterpenoids of Tripterygium regelii. Acta Pharm. Sin. 1989, 24, 75-79.

19. Shen, J.H.; Zhou, B.N. Study on the triterpenoids of Tripterygium regelii. Acta Bot. Sin. 1992, 34, 475-475.

20. Lee, B.W.; Seo, W.D.; Gal, S.W.; Yang, M.S.; Park, K.H. Quinone methide triterpenes from Tripterygium regelii. Agric. Chem. Biotechnol. 2004, 47, 77-80.

21. Hori, H.; Pang, G.M.; Harimaya, K.; Iitaka, Y.; Inayama, S. The absolute configuration of regelidine, a novel 6-nicotinoyl dihydroagarofuran sesquiterpene alkaloid from Tripterygium regelii. Chem. Pharm. Bull. 1987, 35, 4683-4686. [CrossRef]

22. Han, B.H.; Yang, H.O.; Ryu, J.H. Tripterregeline A, B and C, sesquiterpene alkaloids from Tripterygium regelii. Arch. Pharm. Res. 1989, 12, 310-312. [CrossRef]

23. Fan, D.; Zhu, G.Y.; Chen, M.; Xie, L.M.; Jiang, Z.H.; Xu, L.; Bai, L.P. Dihydro- $\beta$-agarofuran sesquiterpene polyesters isolated from the stems of Tripterygium regelii. Fitoterapia 2016, 112, 1-8. [CrossRef] [PubMed]

24. Fan, D.; Parhira, S.; Zhu, G.Y.; Jiang, Z.H.; Bai, L.-P. Triterpenoids from the stems of Tripterygium regelii. Fitoterapia 2016, 113, 69-73. [CrossRef] [PubMed]

25. Schaneberg, B.T.; Green, D.K.; Sneden, A.T. Dihydroagarofuran sesquiterpene alkaloids from Maytenus putterlickoides. J. Nat. Prod. 2001, 64, 624-626. [CrossRef] [PubMed]

26. Duan, H.Q.; Takaishi, Y.; Momota, H.; Ohmoto, Y.; Taki, T.; Jia, Y.F.; Li, D. Immunosuppressive sesquiterpene alkaloids from Tripterygium wilfordii. J. Nat. Prod. 2001, 64, 582-587. [CrossRef] [PubMed]

27. Lhinhatrakool, T.; Prabpai, S.; Kongsaeree, P.; Sutthivaiyakit, S. Antiplasmodial sesquiterpene alkaloids from the roots of Maytenus mekongensis. J. Nat. Prod. 2011, 74, 1386-1391. [CrossRef] [PubMed]

28. Santos, V.A.F.F.M.; Regasini, L.O.; Nogueira, C.R.; Passerini, G.D.; Martinez, I.; Bolzani, V.S.; Graminha, M.A.S.; Cicarelli, R.M.B.; Furlan, M. Antiprotozoal sesquiterpene pyridine alkaloids from Maytenus ilicifolia. J. Nat. Prod. 2012, 75, 991-995. [CrossRef] [PubMed]

29. Duan, H.Q.; Kawazoe, K.; Takaishi, Y. Sesquiterpene alkaloids from Tripterygium hypoglaucum. Phytochemistry 1997, 45, 617-621. [CrossRef]

30. Brüning, R.; Wagner, H. Übersicht über die celastraceen-inhaltsstoffe: Chemie, chemotaxonomie, biosynthese, pharmakologie. Phytochemistry 1978, 17, 1821-1858. [CrossRef]

31. Lee, H.J.; Waller, G.R. Biosynthesis of pyridine alkaloids from Tripterygium wilfordii. Phytochemistry 1972, 11, 2233-2240. [CrossRef]

32. Wang, R.; Chen, R.; Li, J.; Liu, X.; Xie, K.; Chen, D.; Peng, Y.; Dai, J. Regiospecific Prenylation of Hydroxyxanthones by a Plant Flavonoid Prenyltransferase. J. Nat. Prod. 2016. [CrossRef] [PubMed]

33. Bartok, B.; Firestein, G.S. Fibroblast-like synoviocytes: Key effector cells in rheumatoid arthritis. Immunol. Rev. 2010, 233, 233-255. [CrossRef] [PubMed]

34. Pap, T.; Müller-Ladner, U.; Gay, R.E.; Gay, S. Fibroblast biology: Role of synovial fibroblasts in the pathogenesis of rheumatoid arthritis. Arthritis Res. Ther. 2000, 2, 1.

35. Noss, E.H.; Brenner, M.B. The role and therapeutic implications of fibroblast-like synoviocytes in inflammation and cartilage erosion in rheumatoid arthritis. Immunol. Rev. 2008, 223, 252-270. [CrossRef] [PubMed]

36. Nakayama, H.; Yaguchi, T.; Yoshiya, S.; Nishizaki, T. Resveratrol induces apoptosis MH7A human rheumatoid arthritis synovial cells in a sirtuin 1-dependent manner. Rheumatol. Int. 2012, 32, 151-157. [CrossRef] [PubMed]

37. Wang, H.; Jia, X.; Sui, C.; Zhao, Y.; Mei, Y.; Zheng, Y.; Zhang, Z. Effects of thapsigargin on the proliferation and survival of human rheumatoid arthritis synovial cells. Sci. World J. 2014, 2014, 605416. [CrossRef] [PubMed]

Sample Availability: Samples of the compounds $\mathbf{1}$ and $\mathbf{2}$ are available from the authors.

(C) 2016 by the authors; licensee MDPI, Basel, Switzerland. This article is an open access article distributed under the terms and conditions of the Creative Commons Attribution (CC-BY) license (http://creativecommons.org/licenses/by/4.0/). 